\title{
UNHELPFUL HELP: THE SOCIAL WORK PROFESSION'S RESPONSE TO MASS POVERTY IN SOUTH AFRICA
}

\section{Victor Chikadzi, Edmarié Pretorius}

\section{INTRODUCTION}

This article begins by describing poverty in South Africa, examining systemic responses to it, and reflecting upon social work's role in poverty alleviation. In so doing, it takes a brief historical detour to trace social work's roots in South Africa, showing that from its inception the profession has been hard pressed to find meaningful solutions to poverty, and make a significant impact on poverty eradication in South Africa. Since social work has always been intimately tied to social welfare, it has been prone to political manipulation, despite its social justice value base. Social work in South Africa drew on foreign theories and models of practice that did not necessarily acknowledge or take into account diverse local realities and indigenous practices (Gray, 2003; Gray \& Allegritti, 2002; Gray \& Allegritti, 2003; Osei-Hwedie, 2002). Sixteen years after democracy these imperialistic influences (Midgley, 1981) continue to have a profound impact on social work education and practice in South Africa. As a result, social work does little more than manage and maintain poverty at "acceptable" levels instead of constructively contributing to its eradication. The profession has largely failed to adopt a proactive, structural focus in the training of students and the implementation of povertyalleviation interventions. Instead reactive, ameliorative, remedial and curative approaches that prevent the profession from contributing significantly to the alleviation of mass poverty in South Africa are followed.

\section{CONTEXTUALISING POVERTY IN SOUTH AFRICA}

Despite South Africa's classification as a mix of first and third world countries, the majority of households in South Africa are either poor or vulnerable to poverty (May, 2000). Definitions of poverty depend on the measures used. The Municipality Outreach Project Newsletter (2009) explains that when using the dollar-a-day measurement, poverty in South Africa can be shown to have decreased from 1803394 (4\% of the population) in 1996 to 942731 (2\%) in 2007. However, if the relative poverty measure is applied, the number of people living in poverty increases from 17060571 (40.6\% of the population) in 1996 to 20551295 (42.9\%) in 2007 (Municipality Outreach Project Newsletter, 2009). Using the measure of the proportion of households living below a certain fixed level of income, the Presidency released a report in 2008 that indicated that there was a reduction in both absolute income poverty (income of poor people) and relative income poverty (gap between average income of poor people and the poverty line (RSA, Presidency Report, 2008). There had been a decrease of $5 \%$ of the population living below the poverty line of R322 per person [per month] between 1995 and 2005, and when using the R174 per person [per month] poverty line the $3 \%$ number of households in 1995 decreased to $2 \%$ in 2005 (RSA, Presidency Report, 2008). Therefore, focusing only on income as the criterion of poverty measurement underestimates the extent of poverty in South Africa.

Poverty is a complex phenomenon and an "inherently ... contested concept" (Alcock, 2006:4), given that there is no universally accepted definition or consensus about whether or not absolute or relative poverty should be measured. Absolute poverty is usually measured by per capita or household income (De Beer \& Swanepoel, 2000; Swanepoel \& De Beer, 2006; World 
Bank, 1975). While per capita or household income is also the unit of measurement in relative poverty, the overall extent of poverty is a comparative figure relative to the average national per capita or household income (De Beer \& Swanepoel, 2000; Greeff, 2004).

Two other broadly defined forms of poverty are case poverty and mass poverty. Case poverty refers to a situation where an individual or family suffers poverty in a predominantly affluent society. The individual or family's poverty becomes more visible when compared to the general living standards within that particular community; they can be taken care of by the community or welfare and church actions. On the contrary, mass poverty denotes a situation where a community as a whole is visibly poor with few noticeable better-off individuals or families (Bakhit, 1996; Swanepoel \& De Beer, 2006).

Mass poverty is a characteristic feature of many developing countries and in particular in subSaharan Africa, where absolute poverty is predominant. Within the sub-Saharan context mass poverty is more pronounced in rural areas and urban informal settlements (Swanepoel \& De Beer, 2006). Approximately $72 \%$ of South Africa's poor live in the rural areas (RSA, White Paper for Social Welfare, 1997). The distribution of wealth and income in South Africa is documented as among the most unequal in the world (Centre for Socio-Legal Studies, 2005); this is problematic, because for a country to prosper, it should utilise the potential of the entire population at its disposal (Greeff, 2004). "The circumstances of people experiencing mass poverty in South Africa are worsening, especially in the rural areas, due to a legacy of unequal access, control and distribution of resources" (Strydom \& Tlhojane, 2008:34).

In Africa the roots of mass poverty can be traced back to the period of colonialism, urbanisation and industrialisation. During this period indigenous ways of life and livelihoods were disrupted, plunging the majority of the natives into destitution because they were challenged by, and unable to cope with, the pace and hostile ways of urbanisation and industrialisation. When people are continuously treated without respect for their dignity, irreparable psychological damage that far outweighs the material poverty endured is generated (Novak, 1997). Consequently mass poverty has been inherited and grown cumulatively from generation to generation with increased population growth within the context of limited resources.

Alcock (2006) observes that there are two main schools of thought about the causes of poverty. The first supports an individualistic perspective. Proponents of this view blame the individual for being poor and argue that, on the one hand, the genetic factors which relate social status to apparently inherited characteristics such as intelligence and, on the other, psychological factors which lead to the under-achievement of individuals because of acquired or developed personality traits, e.g. incompetence, laziness and unwillingness to work hard, result in their being poor (Alcock, 2006). This approach is based on the dynamic and contentious debate around "nature - how we are born - and nurture - how we develop as people" (Alcock, 2006:38). This view, as we shall discuss below, has had a profound impact on the development of social work theory and practice since its inception. This is mainly seen in case- and groupwork approaches to social work, which adopted an individualist perspective in treating clients' problems. The individualist perspective pathologises people's problems and it largely denotes that a client's problem is a result of the shortcomings or malfunctions within the individual.

On the other hand, there is the structural perspective (as argued by Alcock, 2006) and Cunningham and Cunningham (2008); advocates of this view look at poverty as a product of dynamic social forces within the broader economic, social and political realm. Although many 
policies have been developed to combat poverty within the predominantly capitalist economy in South Africa, very little success has been achieved. Hence proponents of the structural perspective see poverty not as a consequence of the failings of the poor, but rather as being the result of the inadequacies of the policies designed to combat poverty (Alcock, 2006; Cunningham \& Cunningham, 2008). It is perhaps time to challenge those who claim to be able to change social structures through political action to implement the necessary changes so that the impact of doing so becomes evident in the reduction of mass poverty.

Alcock (2006:4) observed that "poverty is not just a state of affairs, it is an unacceptable state of affairs - it implicitly contains the question, what are we going to do about it?" Despite what the causes of poverty are, we are questioning whether the social work profession is relevant and rigorous in education and practice in attempting to contribute to poverty eradication. The profession has largely, though not exclusively, been influenced by a Westernised pathological model of practice which individualises people's problems and focuses mainly on micro-level practice. In developing countries and specifically in South Africa this approach has proved to be ineffective in dealing with the complexities of mass poverty in a culturally diverse society. Although there has been a shift in welfare service delivery since 1994 to a developmental and integrated service delivery approach and a more pro-change attitude, the profession's accommodating and pliable stance has contributed to maintaining an unacceptable state of affairs on poverty that should be challenged.

Smale, Tuson and Statham (2000:18) observed that "those who use, and are required to use, social work services continue overwhelmingly to be poor and disadvantaged." In the same vein Cunningham and Cunningham (2008) noted that there is an unspoken assumption that poverty provides a context for other problems presenting themselves that are likely to bring clients into contact with social services. Poverty is the underlying factor that largely gives "birth" to a wide array of problems that compels people to seek social work intervention. Thus, the eradication of mass poverty can contribute to minimising peoples' contact with social services.

According to Kaseke (2007:1), "Poverty remains the biggest challenge to human welfare in Southern Africa and the world at large as it is preventing millions of people from realising their full potential." There is a need for critical reflection and analysis of the profession's response to poverty to realise the true impact of its interventions on the lives of those who seek social work services.

\section{THE HISTORICAL ROOTS OF SOCIAL WORK IN SOUTH AFRICA}

In critically examining social work's role in relation to poverty, it is essential to take a brief historical detour that traces the birth of social work in South Africa. Right from its inception "both colonialism and apartheid shaped the evolution of the nature, form and content of social welfare policy in South Africa" (Patel, 2005:66). Far from embodying the principles of human rights and social justice, social work practice was exclusionary and framed along segregationist lines. The tune which educators and practitioners played was that of the colonial masters. With its unjust and exclusionary character under apartheid, social work was firmly controlled by the political order of the day. Social work programmes were politically designed and the reliance of social work educators and practitioners on government funding and space for their existence meant compromising the profession's self-determination. To some extent social work lost its autonomy, a value that has largely not been recovered to this present day. The social work curricula adopted by training institutions represented the imposition of a distorted world view which did not correspond with the realities of the diversity of the African context. In 1929 the 
Carnegie Commission of Enquiry conducted an investigation into the poor white problem, which represented the first scientific and interdisciplinary approach to the study of social problems in South Africa (Nicholas, 2010). However, the unique problems of the majority black populations were not considered and the ways employed to help poor people were specifically focused on minority white needs. Although the assistance was later extended to other population groups, their unique and culture-specific needs and preferences were not taken into account (McKendrick, 1987).

Midgley (1981:150) observed that social work educators and practitioners were influenced by and adopted Western models, concepts and themes uncritically and aided the diffusion of inappropriate approaches. He concluded his argument by stating that "because of its dependence on Western ideas, social work education in developing countries is unsuited not only to the demands of practice but to the amelioration of pressing social problems", with poverty being one of the most salient. Thus since its inception social work education and practice embodied the negation of Africans' specificity and the African context. During the late 1980s progressive social welfare and developmental organisations emerged. The social welfare model that developed from the vision, principles, conceptualisation and approaches in service delivery practised by these organisations "was strongly oriented toward a social development approach to social welfare" (Patel, 2005:83). Even though there is a change in the focus of social work education in the past six years, curricula are still predominantly influenced by a Eurocentric world view of technocratic micro-practice and managerialism, resulting in approaches often inappropriate to address and deal with the uniquely South African and African challenges of underdevelopment, among which mass poverty is central.

Sixteen years into the post-apartheid era social work is struggling to regain its autonomy. The welfare terrain is highly politicised, and programmes continue to be politically determined both by design and default:

- By design, in the sense that government social workers are bound by statutory obligations which require them to engage predominantly in curative and rehabilitative services not very helpful in ameliorating mass poverty;

- By default in the sense that social workers in the non-governmental (NGO) sector also rely to a large extent on government funding which in direct and subtle ways curtails their autonomy and self-determination.

Instead of being scriptwriters, social workers assume the acting role which is dependent on the scriptwriters. No matter how effective and efficient social workers are, the fact that they are implementing interventions that are mainly reactive and remedial creates the perception that they are ineffective and inefficient. Due to the profession's reliance and dependence upon the state, the activities of social workers, both within government and the NGO sector, are still largely influenced by those in power. Dominelli (2002:32) noted that "the subjugation of social work's remit to economic exigencies and political interventions is a function of its position as a dependent profession." Social work is implemented within institutional mechanisms and constraints prevailing within the given socio-economic and political context. The new manifesto for social work stresses the need for redefining the profession in terms of "its value base and not the function that it serves for the state" (Cunningham \& Cunningham, 2008:49). Similar problems as those highlighted in the manifesto beset the social work profession in South Africa. Reverting back to the value base will guard against social work practice being pliable to the agenda of government. 
Paradoxically, the profession is dependent on government, despite the fact that governmental policies contribute to perpetuating mass poverty. How then can social work have a meaningful impact on poverty alleviation? The social work profession continuously seeks to safeguard the self-determination of services users; ironically the majority of practitioners do not in themselves have the right to self-determination. How can social work facilitate the selfdetermination of service users while its own self-determination is compromised? The profession has lost its self-determination because the role of practitioners in many instances becomes that of intermediaries between the benefactors (government and other funders) and beneficiaries (service users). The agenda for social work must be shaped by the profession's value base rather than the dictates of government.

The profession's self-determination is necessary in the fight against mass poverty in South Africa. Social workers seem to be equipped to engage in roles that can minimise the glaring inequalities and contribute to maintaining mass poverty at acceptable levels; this is enough to prevent popular revolts, but it does not facilitate the eradication of mass poverty. In this vein, social work can be viewed as an instrument of government which exists to maintain the status quo through its palliative role that provides a partial cure for the worst effects of capitalism (Jones \& Novak, 1999). In essence, willingly or unwittingly many social workers in South Africa are actively participating in maintaining and extending the neo-liberal agenda.

Given the above, determining how social work can play a meaningful role in eradicating mass poverty becomes problematic. Becker $(1997: 114)$ is dismissive about the contribution of social work to poverty eradication when she argues that "Social workers have little understanding of the complex processes that generate and maintain poverty; they have limited insight into how their political and welfare ideologies and attitudes to poverty affect their daily practice with poor people; they have failed to place poverty on the agenda for social work theorising, education and practice."

That the profession has a commitment to ensuring citizenship, equity and social justice for all people is more rhetoric than reality. The social work mission is currently informed more by its compromised position as a dependent and functional instrument of the state than its own value base. Lombard (2008:160) observed that the welfare terrain and "in particular social work have failed citizens in the area of advocating for social justice and human rights". Social justice requires that we challenge the existing status quo. Currently government's imposed agenda for social work denotes that no significant poverty eradication will ensue and that we will continue on the path of poverty management instead of poverty eradication.

\section{THE THEORETICAL FRAMEWORK OF SOCIAL WORK PRACTICE IN SOUTH AFRICA}

According to Shivji (2007), the interrogation of social work's response to mass poverty requires that we ask questions such as: Are we serving the best interests of our clients? Are we contributing to the great cause of humanity, the cause of emancipation from oppression, exploitation and deprivation? Or are we engaged, unconsciously, in playing to the tune set by others? Is social work really contributing to mass poverty eradication?

In reflecting on social work's role in relation to mass poverty, it is essential that we look primarily at the conventional social work methods and practices or "toolkit" with which educators and practitioners are equipped. The primary methods and practices that constitute the theoretical framework of social work practice in South Africa will be discussed briefly. 


\section{CASE-BASED ANALYSIS OF MICRO AND MESO PRACTICE}

Anita is a social worker in Dimbaza, one of the informal settlements around Johannesburg. She began working in this community in 2005. Most of her clients are unemployed, single parents who live in squalid conditions and survive below the poverty datum line. Almost everyone residing in this informal settlement is poverty-stricken. When Anita began working in this community in 2005 she managed to achieve the following: helped poor mothers to receive child-care grants, arranged a soup-kitchen programme to feed members of the community, rendered counselling services to community members, collected clothes and blanket donations to keep many of the families warm in winter, run literacy classes for 150 adults. Many members of the community applaud and appreciate the help they received from Anita; without a doubt she made a difference to this community. We are now in 2011 and Anita is still working in Dimbaza, and feels that her services are critical to this community, as indeed they are. Reflecting on the progress she has made since she began to working in Dimbaza, Anita says "I have done a lot for this community, my case records show that I have seen more than 900 clients for counselling in each year that I have worked here." However, not much has changed in the seven years that Anita has worked there, the people are still poor, struggling to barely survive each day; they still live in shacks, largely unemployed, under very poor hygienic conditions. For many inhabitants of Dimbaza this will be their lived reality until they die.

The case of Anita the social worker and the Dimbaza community is reflective of the lived reality of many social workers and the communities they serve through micro and meso social work practice. There is no doubt that Anita is doing her best to service her clientele base. But when looking at her seven years of service to the Dimbaza community, one would need to objectively ask the questions posed by Shivji (2007): Is Anita serving the best interests of her clients? Is she contributing to the greater cause of humanity, the cause of emancipation from oppression, exploitation and deprivation? Her micro and meso social work efforts have only served to promote the survival of community members, while maintaining them in their poverty. How helpful is this help? The core problems confronting the Dimbaza community are largely reflective of the unjust socio-economic and political structure of South African society rather than the fault of her clients. This kind of social work intervention is not very helpful because it hardly facilitates the eradication of poverty. Social workers need to begin to move beyond their "first aid" efforts and work to address issues of economic marginalisation and deprivation of their clients in order to promote a decent existence for social work service users.

The prominence of the case work approach can be traced back to the historical roots of social work. Midgley (1981) noted that in the early days of social work's inception, social problems were conceptualised as individual maladjustment and it was social work's duty to treat these emotional malfunctions by interpersonal relationships. When working with mass poverty and its complex effects in South Africa and other third world countries that force people to seek social work intervention, it is clear that reliance on, or the application of, only this method of help is not appropriate and less helpful, because the individual becomes the main object of analysis and action. This directly and subtly expects of the individual to take full responsibility and adjust to the situation s/he is confronted with. A more holistic approach towards the person in the environment is imperative, because change should also take place in the environment. Holman (1993) observed that the case work approach only serves to mask the social, economic and political forces operating in people's lives which maintain their condition of deprivation. Therefore, it is questionable why this approach dominates the social work training curricula and practice settings so extensively. In South Africa the majority of social workers within 
government and the NGO sector continue to engage in the inclusionary and exclusionary process of screening the deserving and non-deserving poor to qualify for social grants, our most popular strategy in fighting mass poverty. Interventions at this level only serve to address the symptoms of a structurally flawed socio-economic and political system. In essence, when dealing with mass poverty, case work interventions can be likened to the actions of a cleaner who, upon finding an open tap in the house, chooses rather to start mopping the floor without closing the tap.

Meso practice as a direct method of intervention in social work is used to enable people to meet their personal needs within the group context as well as to achieve shared group goals and objectives. When looking at the complexities of underdevelopment and mass poverty in South Africa, it is evident that this conventional approach can be applied on a preventative, promotive and educational level to assist groups of people to organise themselves for social action. However, this method of intervention on its own is, like its case work counterpart, not the most effective way to approach underdevelopment and mass poverty. It is highly unlikely that micro and meso interventions will provide solutions for people's basic needs of housing, education, health, food, income and sustainable livelihoods. Midgley (1981) confirmed that it is impracticable to think that these social work methods can effectively be used to deal with problems of mass poverty in the third world. It is therefore imperative for social work theory and practice in South Africa to rebut the curative agenda in favour of adopting a structural perspective in social work theory and practice, which has largely been elusive. Continuing to individualise clients' problems, when it is common knowledge that the root causes of these manifestations mainly originate from the system, is highly problematic.

\section{Macro practice}

Macro intervention in social work mirrors work with communities, organisations and government to bring about change and improve the welfare of the broader society. Collective responsibility and effort by communities are usually reflected in macro intervention. Multiple innovative strategies that might involve community development programmes and projects to ameliorate mass poverty, as well as advocating for policy changes at different levels within the nation state to better the lives of service users, can be classified as macro-level interventions. The focal point for social work theory and practice should be at this level, if the profession wants to influence the implementation of poverty-reduction initiatives and contribute significantly towards the war on mass poverty. However, in South Africa the basis on which practitioners can make valid claims for macro intervention is rather slim and insignificant. The shortage of qualified social workers and the overwhelming burden of remedial social services have resulted in the very partial realisation of community social work in post-apartheid South Africa (Brown \& Neku, 2005). It is evident that social work continues to focus on maintenance approaches with hardly any impact on mass poverty amelioration.

Furthermore, the social welfare budget in South Africa reflects that the bulk of social welfare expenditure is skewed in favour of social security rather than social services (Lombard, 2008). Given the context of the post-apartheid welfare dispensation in South Africa, government was compelled to expand the social security system as a strategy to alleviate poverty, but at the cost of other social services. Because of budgetary constraints, it is almost impossible for social workers to plan and implement macro-level interventions.

Social security as a macro intervention by government has become a contentious issue because it is framed by some practitioners as developmental. The "developmental" claim is refuted, 
because the amounts given are so small they only help to sustain people in their poverty and hardly contribute to development, thus enabling people to exit poverty. Lombard (2008:161) noted that "the government embraces social security as its priority anti-poverty strategy". Social security provisions have also not been administered and implemented in conjunction with exit strategies that will wean people from depending on cash transfers. By implication it means that government is managing poverty instead of implementing strategies to eradicate poverty. Thus instead of a hand-up approach (interventions that enable people to work and actively participate in taking charge of their lives), practitioners are championing a hand-out approach, which feeds dependency. Lombard (2008:156) mentioned that "although social grants are impacting on the survival of the poor, the level of poverty and inequality has not changed significantly". Therefore social grants necessitate that the majority of poor people will continue to feed on crumbs. Social work's social justice mission should be to advocate for opportunities for all people to be independent, participate in and take control of, and responsibility for, their own destinies. Social work cannot respond to this call faithfully as long as the state continues to dictate the social work agenda. It is important that the profession asserts its right to self-determination, because by continuing to be a dormant instrument of the state, its impact on mass poverty will remain insignificant.

Although there are some organisations that focused interventions on a macro level and social workers who were intervening at this level had managed to bring about positive changes in the lives of service users, the profession cannot claim that it is doing enough to address mass poverty. Although some training institutions have been championing new and creative methods for macro interventions, practitioners hardly find it possible to implement these strategies due to the restraining organisational cultures which restrict them to technocratic micro interventions. Where the organisational culture is permissive of macro practice, resource constraints almost always curtail such efforts. In addition, expansive growth in macro intervention is also unlikely because to achieve it requires that the macro agenda permeates the entire social order, whilst at the same time retreating from the less helpful therapeutic agenda of social work that currently dominates the education and practice terrains in social work.

\section{The social development approach}

Social development, a macro-practice intervention model, is embodied in the South African White Paper for Social Welfare (RSA, White Paper for Social Welfare, 1997) and reflects the South African government's pursuit of developmental social welfare. While there has been much debate about what this really entails, it is clear that the developmental social welfare notion embraces the traditional approaches to social welfare and simultaneously highlights the importance of the social development approach. Midgley (1995:25) defined social development as "a planned process of social change designed to promote the well-being of the population as a whole in conjunction with a dynamic process of economic development." The social development approach is a terrain on which social workers can claim moral superiority in macro practice, especially when looking at the synergetic linkage between social and economic policies embraced within this approach. However, as long as social policy plays a subsidiary role to economic policy, this moral high ground can only be claimed in theory. Social development requires collaboration between the economic and social sectors to coordinate the finding of a true structural solution. However, it is doubtful whether there is political willingness to facilitate this process (Hölscher, 2008).

Many social work educators and practitioners understand and envision how social development as a macro intervention practice model can contribute to the eradication of poverty, but 
currently there is little evidence to show how the social development approach is impacting on poverty and inequality on a structural level (Lombard, 2008). The Poverty Relief Fund's R640 million channelled through the Department of Welfare between 1997 and 2004, which was earmarked for anti-poverty programmes that were intended to relieve and alleviate poverty, neither made a change to developmental social work nor became a prominent feature of the South African welfare system (Poggenpoel \& Olivier, 2005).

There is a need to develop programmes that impact on socio-economic objectives and the structural origins of mass poverty and inequality. Without having a direct and observable impact on the structural roots of poverty, the social work educators and practitioners are continuing to address symptoms and not the origins of poverty. Therefore a lack of developmental programmes that impact on the root causes of mass poverty and inequality mean that the social work profession will remain on a poverty-management path which addresses and minimises the worst effects and claims transitory victories against poverty, but fails to contribute meaningfully to the eradication of poverty.

\section{CASE-BASED ANALYSIS OF MACRO PRACTICE}

Julia is a social worker who specialises in community work. Community work as an area of special interest developed for Julia after she become disgruntled by the fact that there was very little that she could do to change people's circumstances through case work services at Child Welfare. In 2008 Julia pioneered an initiative to run some income-generating projects in Sicelo Township in Gauteng. A total of 160 community members were trained in at least one of the following trades: baking, welding, sewing and poultry farming. After the completion of training, capital of R100 000 was given to each of the projects and they began running their income-generating activities. In 2010 Julia became despondent, having realised that most of her clients were still living in poverty, because nothing much had changed in their circumstances. The projects were not performing well owing largely to the stiff competition they faced from big companies that operated along the same business lines as the incomegenerating projects. This is what Julia had to say: "My clients are producing quality products but they can't compete with these big companies. Most of them are giving up on the projects because nothing much in their circumstances has changed. If I had the power, I would close down these big companies, the playing field is not even; my clients can't compete against such well-established and resourced companies."

Julia's work in the Sicelo Township resembles widespread efforts by social workers who mainly engage in macro practice in South Africa. Julia worked to ensure that her clients are capacitated through skills training and she facilitated their getting funding to initiate their own incoming-generating ventures. In some countries similar efforts have become a familiar route out of poverty for the poor. However, when looking at the South African context, research done by Chikadzi (2009) and Netshivhazwaulu (2010) shows many such efforts are reaping mediocre results for poor people in several communities. In Julia's case she did everything right; the only problem is that the economic environment is hostile to small businesses because of the stiff competition from well-established companies who trade along similar lines. When looking at this case, it is evident that the macroeconomic environment is not a fair level field to allow small-scale businesses to flourish. The only solution would be to work at a political level to lobby for government intervention to put in place legislation and measures that protect small business ventures by the poor. This is where the interventionist nature of social development comes into play, as government purposefully intervenes in the economy to protect and promote pro-poor growth policies. However, at present there seems to be a lack of political will on the 
part of government to craft organised efforts to promote social welfare and eradicate poverty. Consequently, social work help becomes less helpful as a result of the constraining nature of the structural environment within which it takes place. We therefore argue that, social work practice should be more structurally focused and this will translate into tangible benefits for our client base.

\section{THE MISSING LINK: ALTERNATIVE THEORISING IN SOCIAL WORK}

The absence of alternative theorising seems to be the dominant weaknesses of the social work curriculum. The overriding importance of a strong complementary theoretical base and its conspicuous absence in social work practice in South Africa, Africa and to a lesser extent globally is worrying. Theory does not refer to existing conventional theories related to case, group and community work; these are plentiful but not always applicable and helpful within the South African context. Theory refers to context-specific alternative theory that unravels the complexities of the South African practice terrain. The absence of alternative theorising implies that the social work profession is trying to change a world that is not fully understood. Therefore it often results in the unquestioning implementation of existing theories, which leads to inappropriate and unsuccessful initiatives in dealing with mass poverty in a diverse society within the South African context. It is alternative indigenous theories within the larger context of theory that should guide the content of the social work curriculum and practice interventions. One of the intentions of the new Bachelor of Social Work (BSW) qualification was "to produce social workers who understand the impact of the political and socio-economic context on social welfare and social work and who consequently wish to address poverty and inequality by tackling their structural causes" (Lombard, 2008:165). However, it is questionable how such an understanding can adequately be attained by social workers in the absence of relevant and rigorous theorising?

In the absence of alternative theorising, social work educators and practitioners fall into the trap of oversimplifying and in turn distorting their world views because of the lack of adequate conceptualisation. How can the social work profession - in the absence of alternative indigenous theory - understand why poverty in a democratic South Africa has continued to worsen in relation to poverty in the apartheid era? How can the profession - without alternative theorising - explain how 10 to 12 years of impressive economic growth in the post-apartheid era have failed to yield significant benefits for the poor? How can the social work profession understand and challenge - without a strong alternative theoretical base - the processes that generate islands of massive wealth in oceans of deep poverty? Theorising is indispensable in any scientific practice, yet conspicuously absent in social work education. The absence of alternative indigenous theorising within the social work profession might explain why the government supports the implementation of programmes that are not necessarily effective in addressing the area specific structural issues related to poverty in South Africa. Social work has become a functionally necessary tool for government and the profession is steered by an imposed therapeutic and treatment agenda at the expense of driving social change to facilitate social development. Thus, far from playing a meaningful role in eradicating poverty, social workers often engage in unsuitable and unsuccessful forms of intervention.

To make a meaningful contribution to the eradication of mass poverty, it is vital that social work students and practitioners have a sound and in-depth theoretical understanding of the causes of underdevelopment, poverty and inequality. The historical and current processes that create poverty need to be interrogated through critical intellectual discourses and theorising within the social work fraternity. This will generate a theoretical understanding of the socio- 
economic and political premises underpinning the unjust status quo. In coming to an understanding of these processes, social work practitioners will no longer label service users as clients but as "casualties" of colonialism, apartheid and neo-liberalism. With such a consciousness social work educators and practitioners can become advocates for human rights and social justice in their truest sense.

Because of the focus on conventional approaches in the social work curricula and constraining agency settings, many social work practitioners are products of a deficient world view. As professionals we cannot seek to understand how clients' conditions are affected by their behaviour and environment without first understanding how we have been affected by our environment and particularly our training and practice settings. William, Tsui and Yan (2009:287) observe that "it would be hypocritical for practitioners to view their clients as products of various factors but not consider the ways in which they themselves have been affected". In many practice settings social workers are inhibited in following what they consider a good model of practice as a result of the constraining nature of their employing agency. Instead practitioners unquestioningly do whatever is required of them in accordance with agency procedures and policies; thus social work practitioners become "victims" of imposed agendas and they in turn help other victims (clients). Thus, in many cases victimhood becomes the central theme underlying the practitioner and client relationship. Instead of tackling the underlying problem, for example mass poverty, practitioners end up responding to the diverse symptoms of the major problem when helping clients. We need to recognise and acknowledge that much social work practice takes place within and around poverty, and hence practice intervention with clients without seeking to change this area is self-defeating (Cunningham \& Cunningham, 2008).

\section{REPOSITIONING THE ROLE OF SOCIAL WORK IN RELATION TO MASS POVERTY IN SOUTH AFRICA}

The significance of the impact and role of the social work curriculum cannot be overstressed when addressing mass poverty. The genesis of transforming social work needs to be located at the point of social work curriculum development. Education is the cornerstone upon which all progress is dependent. Considering the challenges of impressive economic growth rates amidst continued poverty and deprivation for the majority, it is vital that social work training should focus on high-impact intervention strategies to ameliorate mass poverty. This would require a change in focus from the predominance of a therapeutic focus in the curriculum and practice towards more structurally focused training and practice interventions that challenge the existing order. First and foremost social work students and practitioners need knowledge and skills to address poverty at a structural level more than they require case- and group-work treatment techniques. Thus, a relevant and rigorous social work curriculum needs to be developed, informed by alternative indigenous theory to address the unique needs of the present socioeconomic and political realities in South Africa. When working from an Afrocentric perspective, it is important to develop a multicultural curriculum, with an emphasis on African culture (Thabede, 2008). This is supported by Noyoo (2003), who suggested that the social work curricula need to shift from a Western axis to an African one that takes into account diverse local realities. The accommodation of the Afrocentric perspective as a significant part of the knowledge base and practice alongside current Eurocentric intervention theories and practices might contribute towards developing alternative models for Africa which might be useful and applicable (Osie-Hwedie, 2002; Thabede, 2008). 
Social work educators and practitioners need to reflect upon and start exploring possibilities of an alternative world. How can the profession advocate and negotiate to contribute to change on a structural level in a way which will facilitate the creation of an alternative world to the current unjust status quo? This would require a fundamental change in focus from the predominantly therapeutic towards the structural. While this would be no mean feat, it is the small actions that will lead to significant progress which will culminate in grandstand victory. Our social justice and human rights principles bind us to this call. Practitioners should assist poor people to focus and build on their assets to reclaim or gain the power they might have lost or never had and facilitate self-confidence, self-reliance, ownership, empowerment, responsibility, human dignity and personal vision (De Beer \& Swanepoel, 2000; Reyneke, 2009). They should be treated and respected as citizens who are producers and participants in creating the world they are living in. Critical and reflective intellectual discourses on this terrain will give birth to a new type of social work, one that liberates citizens rather than chain service users to the status quo.

Social work cannot continue to only subscribe to therapeutic perspectives if the problem of mass poverty is to be eradicated, because it will make them unwitting perpetrators of the unjust status quo that continues to feed mass poverty. Social workers need to be articulate on issues that relate to access to the means of production for the marginalised and the adoption of full employment policies by government. Such measures ensure that all people have the ability to survive in a cash-based economy as they will be empowered to create and earn income.

Social work educators and practitioners have to consider who the other stakeholders are with whom they have to engage and work with to make a difference in the world of mass poverty in South Africa. The time has come to work in a more cross-disciplinary, multidisciplinary and interdisciplinary way to create possible solutions to mass poverty.

Social work educators and practitioners have to carefully consider what skill set is needed to equip them to address the massive task effectively. Osie-Hwedie (2002:321) argued that "social work knowledge and practice in Africa must emerge from local inputs that should sustain them... therefore social workers in Africa should develop their own cumulative knowledge and define their practice skills". Revisiting the four clusters of roles (facilitative, educational, representational and technical) discussed by Ife (2000) and the true meaning of the roles for developmental workers (enabler and empowerment, mobiliser, educator, counsellor, conferee, broker, networker, mediator and advocate) highlighted by Patel (2005) and Zastrow (2004) might contribute to the profession's understanding of the need to reposition itself in terms of the contribution social work can make to facilitate the eradication of mass poverty in South Africa.

\section{CONCLUSIONS}

In this article it is clear that social work educators and practitioners have to critically reflect on what contribution they make to the eradication of mass poverty. The social work profession needs to evaluate whether it is actively participating in finding workable solutions to mass poverty in South Africa or if the profession is actually unwittingly contributing to the problem. In the discussion it was argued that social work has not been effective in responding to the complexities of mass poverty in South Africa for the following reasons.

Firstly, the colonial trajectory taken by social work at its inception in South Africa has not significantly been altered despite the achievement of democracy. Foreign theories and therapeutic models of intervention continue to dominate the education and practice terrain of 
social work. Social work educators and practitioners have to be much more sensitive to the elements that constitute the African world view and acknowledge the significance of African culture when providing services to Africans (Thabede, 2008).

Secondly, social work remains as it was under apartheid: a tool in the hands of the state that is open to political manipulation. It is highly likely that those in control of government have a vested interest in maintaining the status quo. South African democracy has "failed to deliver full benefits of citizenship to large numbers of people, but conspicuously to local communities in the rural areas, whose circumstances are worsening in absolute and relative terms" (Strydom \& Tlhojane, 2008:34). To this end social work becomes an integral part of a system that denies people the right to development by affording them minimal basic survival. While social work cannot be divorced from the state, the impact of this relationship of convenience needs to be interrogated and progressive pathways charted on how social work can constructively engage the state for the benefit of its client base. It would be a travesty for social work to continue being docile and pliable to the state agenda at the expense of empowerment of citizens.

Lastly, this discussion highlighted the need for critical intellectual discourse on the crisis of poverty. It is in such discursive spaces that we can hope to find new lenses by which to view and confront the spectre of poverty.

\section{REFERENCES}

ALCOCK, P. 2006. Understanding poverty ( $3^{\text {rd }}$ ed). Hampshire: Palgrave Macmillan.

BAKHIT, I.I. 1996. Mass poverty in developing countries: a cultural perspective. In: VON RAVENSBURG, N.G., MUNKNER, H.H., WALTER, V. \& WALTER, T. (eds) Attacking the roots of poverty. Germany: Marburg consult for self-help promotion.

BECKER, S. 1997. Responding to poverty, the politics of cash and care. Harlow: Longman.

BROWN, M. \& NEKU, R.J. 2005. A historical overview of the South African social welfare system and social work practitioners' views on its current status. International Social Work, 48(3):301-312.

CENTRE FOR SOCIO-LEGAL STUDIES. 2005. Poverty and the environment. Johannesburg.

CHIKADZI, V. 2009. An analysis of community participation in income generating projects at the Tembisa/Kempton Park Developmet Center. Johannesburg: University of the Witwatersrand. (Unpublished MA Social Development Research report)

CUNnINGHAM, J. \& CUNNInghaM, S. 2008. Sociology and Social Work. Exeter: Learning Matters Ltd.

DE BEER, F. \& SWANEPOEL, H. 2000. Introduction to development studies ( $2^{\text {nd }}$ ed $)$. Cape Town: Oxford University Press.

DOMINELLI, L. 2002. Anti-oppressive social work theory and practice. New York: Palgrave MacMillan.

GRAY, M. 2003. Editorial "Indigenous social work, culturally sensitive social work or plain "good social work": Are they one and the same?" Social Work/Maatskaplike Werk, 39(4):xix-xxii.

GRAY, M. \& ALLEGRITTI, I. 2003. Towards culturally sensitive social work practice: re examining cross-cultural social work. Social Work/Maatskaplike Werk, 39(4):312-325. 
GRAY, M. \& ALLEGRITTI, I. 2002. Cross-cultural practice and the indigenisation of African social work. Social Work/Maatskaplike Werk, 38(4):324-336.

GREEFF, J. 2004. Introduction to Sociology: poverty and development. Cape Town: Oxford University Press.

HOLMAN, B. 1993. A new deal for social welfare. Oxford: Lion Books.

HÖLSCHER, D. 2008. The Emperor's new clothes: South Africa's attempted transition to developmental social welfare and social work. International Journal of Social Welfare, 17(2):114-123.

IFE, J. 2000. Community development: community-based alternatives in the age of globalisation $\left(2^{\text {nd }}\right.$ ed). Malaysia: Pearson Education.

JONES, C. \& NOVAK, T. 1999. Poverty, welfare and the disciplinary state. Abingdon: Routledge.

KASEKE, E. 2007. Social protection for poverty reduction in Southern Africa. Paper presented at the Bi-regional Conference on Social Protection and Poverty Reduction. Lord Charles Hotel, Cape Town. South Africa, 6-9 June.

LOMBARD, A. 2008. The implementation of the White Paper for Social Welfare: a ten-year review. The Social Work Practitioner-Researcher, 20(2):154-173.

MAY, J. 2000. Growth, Development, Poverty and Inequality. In: MAY, J. (ed), Poverty and inequality in South Africa meeting the challenge, Cape Town: David Philip Publishers: 1-16.

McKENDRICK, B. 1990. The development of social welfare and social work in South Africa. In: McKENDRICK, B.W. (ed) Introduction to social work in South Africa, Pretoria: Haum Tertiary: 5-19.

MIDGLEY, J. 1981. Professional imperialism: social work in the Third World. London: Heinemann.

MIDGLEY, J. 1995. Social development: The developmental perspective in social welfare. London: Thousand Oaks.

MUNICIPALITY OUTREACH PROJECT. 2009. Newsletter 18 Defining poverty, April 24: $1-3$.

NETSHIVHAZWAULU, G.T.J. 2010. Stakeholders' perceptions about the functioning of Development Centres funded by the Department of Social Development in Gauteng. Johannesburg: University of the Witwatersrand. (Unpublished MA Social Development Research report)

NICHOLAS, L. 2010. The history of South African social work. In: NICHOLAS, L., RAUTENBACH, J. \& MAISTRY, M. (eds) Introduction to social work. Claremont: Juta: 4047.

NOYOO, N. 2003. Social welfare policy, social work practice, and professional education in a transforming: South Africa. Johannesburg: University of the Witwatersrand. (Unpublished doctoral Thesis)

NOVAK, T. 1997. Poverty and the underclass. In: LAVALETTE, M. \& PRATT, A. (eds) Social policy: a conceptual and theoretical introduction. London: Sage Publications. 
OSEI-HWEDIE, K. 2002. Indigenous practice - some informed guesses. Self-evident and possible. Social Work/Maatskaplike Werk, 38(4):311-323.

PATEL, L. (ed) 2005. Social welfare and social development in South Africa. Cape Town: Oxford Press Southern Africa.

POGGENPOEL, S. \& OLIVIER, L. 2005. Investigating the implications of ten years of democracy for women: the role of the Department of Social Development. [Online] Available: http://www.idasa.org.za. [Accessed: 23/06/2010].

RSA. PRESIDENCY REPORT. 2008. Towards a Fifteen year Review Synthesis Report. [Online] Available: http://www.thepresidency.gov.za.

RSA. MINISTRY FOR WELFARE AND POPULATION DEVELOPMENT. 1997. White Paper for Social Welfare, Notice 1108 of 1997. Government Gazette, 386, No. 18166, 8 August 1997. Pretoria: Government Printer.

REYNEKE, R. 2009. Using adventure to increase the emotional intelligence of the poor. Social Work/Maatskaplike Werk, 45(1):47-61.

SHIVJI, I.J. 2007. Silences in NGO discourse: the role and future of NGOs in Africa. Oxford: Fahamu.

SMAle, G., TUSON, G. \& STATHAM, D. 2000. Social work and social problems. Basingstoke: Palgrave.

STRYDOM, C. \& TLHOJANE, M.E. 2008. Poverty in a rural area: the role of the social worker. Social Work/Maatskaplike Werk, 44(1):34-51.

SWANEPOEL, H. \& DE BEER, F. 2006. Community development: breaking the cycle of poverty $\left(4^{\text {th }}\right.$ ed). Landsdowne, South Africa: Juta \& Co Ltd.

THABEDE, D. 2008. The African worldview as the basis of practice in the helping professions. Social Work/Maatskaplike Werk, 44(3):233-245.

WILLIAM, C.K., TSUI, M. \& YAN, M. 2009. Social work as a moral and political practice. International Social Work, 52(3):287-298.

WORLD BANK. 1975. The assault on world poverty: problems of rural development, education and health. Baltimore: Johns Hopkins.

ZASTROW, C. 2004. Introduction to social work and social welfare. New York: Thomson.

Mr Victor Chikadzi; Dr Edmarié Pretorius, Department of Social Work, University of the Witwatersrand, Johannesburg, South Africa. 